\title{
Hemicellulolytic enzymes in P- and S-strains of Heterobasidion annosum
}

\author{
Pekka Maijala, ${ }^{1}$ Marjatta Raudaskoski ${ }^{1}$ and Liisa Viikari ${ }^{2}$ \\ Author for correspondence: Pekka Maijala. Tel: +358 0191 8639. Fax: +358 01918656. \\ e-mail:pekka.maijala@Helsinki.fi
}

1 Department of Botany, PO Box 7, 00014 University of Helsinki, Finland

2 VTT, Biotechnology and Food Research, PO Box 1500, 02044 VTT, Finland
The secretion of several hemicellulolytic enzymes and endoglucanase was studied in S- and P-group strains of a wood-rotting pathogen, Heterobasidion annosum, using enzyme activity assays and isoelectric focusing. In liquid cultures supplemented with birch sawdust or pure xylan, both strains of the fungus produced xylanases, mannanases, endoglucanases and $\alpha$ galactosidases. Low activities were detected in cultures containing only glucose as a carbon source. When S-strain cultures were provided with a carrier matrix, protein secretion to the culture medium started earlier and was significantly increased compared to free cell cultures. This was not the case with the P-strain. In both strains of $H$. annosum the pH of the birch sawdust culture medium fell within $12 \mathrm{~d}$ to below 3.5 , and then started to increase towards the end of the cultivation period. The increase in $\mathrm{pH}$ appeared to correlate with the formation of hemicellulolytic and endoglucanase activities. The isoenzyme patterns of xylanase, mannanase and endoglucanase were typical for P- and S-strains. In P-strain cultures containing xylan, a xylanase with an alkaline pl value was induced which, however, was absent when the Pstrain was grown with the birch sawdust substrate. In the P-strain the mannanase pattern at the early stage of growth was comparable to that of the S-strain at the later stages of growth on birch sawdust medium. Later in the growth of the P-strain, this pattern was replaced by mannanases with more acid $\mathrm{pl}$ values. The relative intensities of the individual endoglucanases varied between the $\mathbf{P}$ - and S-strains.

Keywords: Heterobasidion annosum, secretion, xylanase, mannanase, cellulase

\section{INTRODUCTION}

Heterobasidion annosum is a white-rot fungus that has spread over the whole boreal zone of the Northern hemisphere. In Scandinavia it consists of two intersterility groups, $\mathrm{P}$ and $\mathrm{S}$, which differ in their host specificity: the P-group has a very wide host spectrum attacking mainly Pinus species and Juniperus communis but also Calluna vulgaris, Alnus incana and Betula species, whereas the S-group infects mainly Picea abies (Korhonen, 1978; Stenlid \& Swedjemark, 1988). In Pinus species the fungus first spreads rapidly in the cambium and phloem tissues and then colonizes sapwood. In contrast, colonization of Picea abies is frequently restricted to heartwood tissues (Hodges, 1969).

In $H$. annosum, pectinolytic activity has been studied in $\mathrm{P}$ and S-intersterility groups (Johansson, 1988). A higher pectinolytic activity was observed in the $\mathrm{P}$ - than in the $\mathrm{S}$ - group. In addition, carboxymethylcellulose degrading activity has been detected in the P- and S-strains of $H$. annosum (Maijala et al., 1991). A few reports on cellulolytic and hemicellulolytic enzymes in $H$. annosum have been published (Ahlgren \& Eriksson, 1967; Hütterman \& Volger, 1973; Johansson et al., 1976), but more exact information on the quality and quantity of cellulases and hemicellulases in the $\mathrm{P}$ - and S-strains of $H$. annosum is needed in order to understand their wood degrading mechanisms.

In the present investigation the production of hemicellulolytic and cellulolytic enzymes of $H$. annosum $\mathrm{P}$ - and Sstrains was studied when the mycelia were grown in a synthetic mineral salt medium containing various carbon sources and using synthetic carrier matrices. The cellulolytic and hemicellulolytic enzymes were further analysed by isoelectric focusing. 


\section{METHODS}

Fungus and inoculum. Heterobasidion annosum representing intersterility groups P and S were originally isolated by Dr Kari Korhonen (Forest Research Institute, Vantaa, Finland) from Pinus sylvestris and Picea abies, respectively, from trees grown in southern Finland. Isolates were maintained on $1.5 \%(\mathrm{w} / \mathrm{v})$ malt extract agar in the dark at $4{ }^{\circ} \mathrm{C}$. The conidia were harvested from a three-week-old mycelium in sterile distilled water with a glass triangle. The inoculum contained $1 \times 10^{5}-1 \times 10^{6}$ conidia ( $\mathrm{ml}$ culture medium $)^{-1}$. The germination rate of the conidia was estimated using agar plates supplemented with a mineral salt medium, BW (Brown \& Wilkins, 1985), and birch sawdust.

Media. BW medium, $\mathrm{pH} 4 \cdot 8$, was used in all experiments except where malt extract was added. This medium was originally prepared for Betula species but is suitable for culturing fungi such as H. annosum (Maijala et al., 1991). D-Glucose was added at a concentration of $0.1 \%$ or $1 \%(\mathrm{w} / \mathrm{v})$. For experiments on the effect of other carbon sources on growth and enzyme secretion, glucose was replaced by $1 \%(\mathrm{w} / \mathrm{v})$ beechwood xylan (Lenzing xylan, Austria), $1 \%(\mathrm{w} / \mathrm{v})$ birch sawdust or $1 \%(\mathrm{w} / \mathrm{v})$ pine sawdust (containing $60 \%, \mathrm{w} / \mathrm{w}$, heartwood and $40 \%$, w/w, sapwood). Malt xylan medium contained $1.5 \%(\mathrm{w} / \mathrm{v})$ malt extract supplemented with $1 \%$ beechwood xylan.

Culture conditions. Two different cultivation methods were used; conventional growth in liquid media (free cell cultures) or carrier bound growth (carrier bound cultures). The cultures were grown at $23{ }^{\circ} \mathrm{C}$ in the dark and gently agitated once a day. Samples of the growth medium were removed every third or fourth day for enzyme activity measurements. In the carrier bound cultures the flasks were filled with loosely woven polypropylene carriers as a supporting matrix for the mycelium. To prevent proteolytic autolysis at the end of the culture period, phenylmethanesulphonyl fluoride (PMSF) from a stock solution in ethanol and EDTA was added in the growth medium to give final concentrations of $1 \mathrm{mM}$ and $0.1 \mathrm{mM}$, respectively.

Enzyme assays. The following biochemical assays were performed for the determination of different hydrolytic enzyme activities. All activities were expressed as nkat $\mathrm{ml}^{-1}$ (nmol substrate hydrolysed $\mathrm{s}^{-1} \mathrm{ml}^{-1}$ ). Samples were stored at $-20^{\circ} \mathrm{C}$ until assayed without any apparent loss of enzyme activity.

Xylanase (1,4- $\beta$-D-xylan xylanohydrolase, EC 3.2.1.8) was determined using $1 \%(\mathrm{w} / \mathrm{v})$ commercial birch glucuronoxylan (Roth 2-7500, Germany) in 0.05 M sodium citrate buffer, $\mathrm{pH} 5 \cdot 3$, as a substrate according to the method of Bailey et al. (1992). Enzyme samples were incubated for $20 \mathrm{~min}$ at $50^{\circ} \mathrm{C}$. The reducing sugars were measured as xylose by the DNS method (Sumner \& Somers, 1949).

Mannanase (mannan endo-1,4- $\beta$-mannosidase, EC 3.2.1.78) was determined using $0.5 \%$ locust bean gum (Sigma) in $0.05 \mathrm{M}$ sodium citrate buffer, $\mathrm{pH} 5 \cdot 3$, as a substrate as described by Rättö \& Poutanen (1988). The enzyme samples were incubated for $20 \mathrm{~min}$ at $50^{\circ} \mathrm{C}$ and the reducing sugars measured as in the xylanase asay, but using mannose as a standard.

Endoglucanase (1,4- $\beta$-D-glucan 4-glucanohydrolase, EC 3.2. 1.4) was determined using $1 \%(\mathrm{w} / \mathrm{v})$ hydroxyethylcellulose (Fluka) in $0.05 \mathrm{M}$ sodium citrate buffer, $\mathrm{pH} 4.8$, as a substrate. The enzyme samples were incubated at $50^{\circ} \mathrm{C}$ for $30 \mathrm{~min}$ and reducing sugars were measured as in the xylanase assay, but using glucose as a standard.

$\beta$-Xylosidase (1,4- $\beta$-D-xylan xylohydrolase, EC 3.2.1.37) was determined using $5 \mathrm{mM} p$-nitrophenyl- $\beta$-D-xylopyranoside (Sig$\mathrm{ma}$ ) in $0.05 \mathrm{M}$ sodium citrate buffer, $\mathrm{pH} 4.5$, as a substrate as described by Poutanen \& Puls (1988). The enzyme samples were incubated at $50^{\circ} \mathrm{C}$ for $20 \mathrm{~min}$. The amount of liberated $p$ nitrophenol was measured spectrophotometrically at $400 \mathrm{~nm}$.
$\alpha$-Galactosidase (EC 3.2.1.22) was determined using $1 \mathrm{mM} P$ nitrophenyl $\alpha$-D-galactopyranoside (Merck 654321 ) in $0.05 \mathrm{M}$ sodium citrate buffer, $\mathrm{pH} 5 \cdot 3$, as a substrate. Released $p$ nitrophenol was measured as in the $\beta$-xylosidase assay.

Acetyl esterase (NA-esterase) (EC 3.1.1.6) was determined using $1 \mathrm{mM} \alpha$-naphthylacetate in $0.05 \mathrm{M}$ sodium citrate buffer, pH $5 \cdot 3$, as a substrate according to the method of Poutanen \& Sundberg (1988). The enzyme samples were incubated at $50{ }^{\circ} \mathrm{C}$ for 30 min. $\alpha$-Naphthol was used as a standard.

Acetyl xylan esterase (AXE) was determined using 5\% (w/v) steamed birchwood hemicellulose in $0.05 \mathrm{M}$ sodium citrate buffer, $\mathrm{pH} 5.0$, as a substrate according to the method of Poutanen et al. (1987).

$\beta$-Glucosidase (1,4- $\beta$-D-glucoside glucohydrolase, EC 3.2.1.21) was determined using $1 \mathrm{mM} p$-nitrophenyl- $\beta$-D-glucoside (Merck) as a substrate in $0 \cdot 05 \mathrm{M}$ sodium citrate buffer, $\mathrm{pH} 4 \cdot 8$. The enzyme samples were incubated at $50{ }^{\circ} \mathrm{C}$ for $30 \mathrm{~min}$. The liberated $p$-nitrophenol was measured as in the $\beta$-xylosidase assay.

Protein contents of the culture filtrates were determined after precipitation with cold $\left(4^{\circ} \mathrm{C}\right)$ ethanol by the Lowry method, using bovine serum albumin as a protein standard.

For the measurements of xylanase, mannanase and endoglucanase activities in the ungerminated conidial inoculum, the suspension was sonicated for $30 \mathrm{~s}$ and the free sugars from the suspension were removed by dialysis before the activity assays.

Biomass determination. Biomass of the cultures was determined by filtering the mycelium through preweighed glass fibre filters (Whatman GF-C). The mycelia were rinsed with distilled water and dried at $95^{\circ} \mathrm{C}$ to constant weight.

Statistical analysis. Statistical analysis was performed using the $t$-test procedure provided by SAS (SAS Institute, Cary, USA). Hydrolysis experiments. The hydrolysis of birch glucuronoxylan ( $1 \mathrm{mg} \mathrm{ml}^{-1}$ ) with concentrated culture filtrates (as in isoelectric focusing; see below) was studied in $0.05 \mathrm{M}$ sodium citrate buffer, $\mathrm{pH} 5 \cdot 3$, at $40^{\circ} \mathrm{C}$ for a given time $(1,4$ or $20 \mathrm{~h}$ ). During the incubation the mixtures were stirred magnetically. After hydrolysis the mixtures were immersed in boiling water for $3 \mathrm{~min}$ and centrifuged at $8000 \mathrm{~g}$ for $20 \mathrm{~min}$ to remove the residual solid material. Xylooligosaccharides were assayed by HPLC (Optilab 931 HSRI) using an Aminex HPX-85 column $\left(8 \mu \mathrm{m}, 300 \times 7.8 \mathrm{~mm} \mathrm{ID}, 85^{\circ} \mathrm{C}\right)$ with water as an eluent $\left(0.8 \mathrm{ml} \mathrm{min}^{-1}\right)$ at $37^{\circ} \mathrm{C}$, and an Optilab Multiref $902 \mathrm{C}$ as a detector.

Isoelectric focusing. The proteins from the culture filtrates were concentrated about 20 - to 100 -fold by ultrafiltration in Amicon no. 8400 stirred ultrafiltration apparatus using PM10 membranes $\left(M_{\mathrm{r}}\right.$ cut-off point 10000$)$ at $0-4{ }^{\circ} \mathrm{C}$. If further concentration was necessary, the samples were packed into dialysis tubes and submerged in a $15 \%(\mathrm{w} / \mathrm{v})$ aqueous solution of polyethylene glycol (PEG 20000) at $4{ }^{\circ} \mathrm{C}$ for several hours. Before isoelectric focusing the samples were desalted by dialysis against distilled water on floating membranes (Millipore). Isoelectric focusing was performed with ultrathin $5 \%$ polyacrylamide gels in the Multiphor-II System (Pharmacia-LKB), following the manufacturer's instructions. The $\mathrm{pH}$ gradient was created by Ampholine $\mathrm{pH} 3 \cdot 5-10$ or Pharmalyte $\mathrm{pH} 2 \cdot 5-5$ (Pharmacia-LKB).

Xylanolytic activity was visualized using an agar replica, $\mathrm{pH} 5 \cdot 3$, containing $1 \%(\mathrm{w} / \mathrm{v})$ beechwood xylan. The gels were incubated for several hours at $50{ }^{\circ} \mathrm{C}$. Clear bands in the turbid agar plate demonstrated xylanolytic activity. Mannanase and endoglucanase were localized using the method described by Béguin (1983). For the visualization of endoglucanase activity, the substrate gel contained $0 \cdot 1 \%$ hydroxyethylcellulose and $2 \%$ 
(w/v) agar in $0.05 \mathrm{M}$ sodium citrate buffer, $\mathrm{pH} 4 \cdot 8$. Mannanase activity was detected similarly using the gel containing $2 \%$ $(\mathrm{w} / \mathrm{v}$ ) agar and $0.5 \%$ locust bean gum in $0.05 \mathrm{M}$ sodium citrate buffer, pH $5 \cdot 3$, prepared as described by Rättö \& Poutanen (1988) for mannanase activity measurements. The $0.75 \mathrm{~mm}$ thick substrate gel was placed on top of the electrofocused polyacrylamide gel. Both gels were incubated for 20-40 min at $50{ }^{\circ} \mathrm{C}$. The hydroxyethylcellulose-containing agar replica was stained with $0.1 \%$ Congo Red in water for $20 \mathrm{~min}$, the excess stain being removed with $1 \mathrm{M}$ sodium chloride until the bands became clear. The mannan-containing agar replica was stained similarly, but incubated overnight in the staining solution. Isoelectric points ( $\mathrm{pIs}$ ) were determined by comparison of bands with $\mathrm{pH}$ values measured with a surface electrode (Ingold).

\section{RESULTS}

\section{Growth experiments and activity assays}

The effect of glucose on the secretion of hemicellulolytic and cellulolytic enzymes was tested by adding $0.1 \%$ or
$1 \%(\mathrm{w} / \mathrm{v}) \mathrm{D}$-glucose to the BW culture media. The enzyme activities were compared with those in the media containing $1 \%$ beechwood xylan as the sole carbon source. Cultures of $\mathrm{P}$ - and S-strains inoculated with conidia were grown for $28 \mathrm{~d}$, after which mycelial dry weight, $\mathrm{pH}$, protein content and enzyme activities of the growth media were recorded. In both strains growth of the mycelium was less significant in $0.1 \%$ glucose than in $1 \%$ glucose medium (Fig. 1a). Also in the xylan medium growth appeared to be poor, although the dry weight could not be measured due to the attachment of the mycelium to the insoluble xylan. During $28 \mathrm{~d}$ growth the $\mathrm{pH}$ of the media containing beechwood xylan declined from 3.4 to 3.2 in the P-strain and from 3.4 to 3.3 in the Sstrain. In the glucose media the $\mathrm{pH}$ decreased from $4 \cdot 6$ to 3.2 in the $\mathrm{P}$ - and from 4.6 to 3.4 in the S-cultures.

The level of extracellular protein in all these cultures was undetectable, but it could be shown that xylanase,
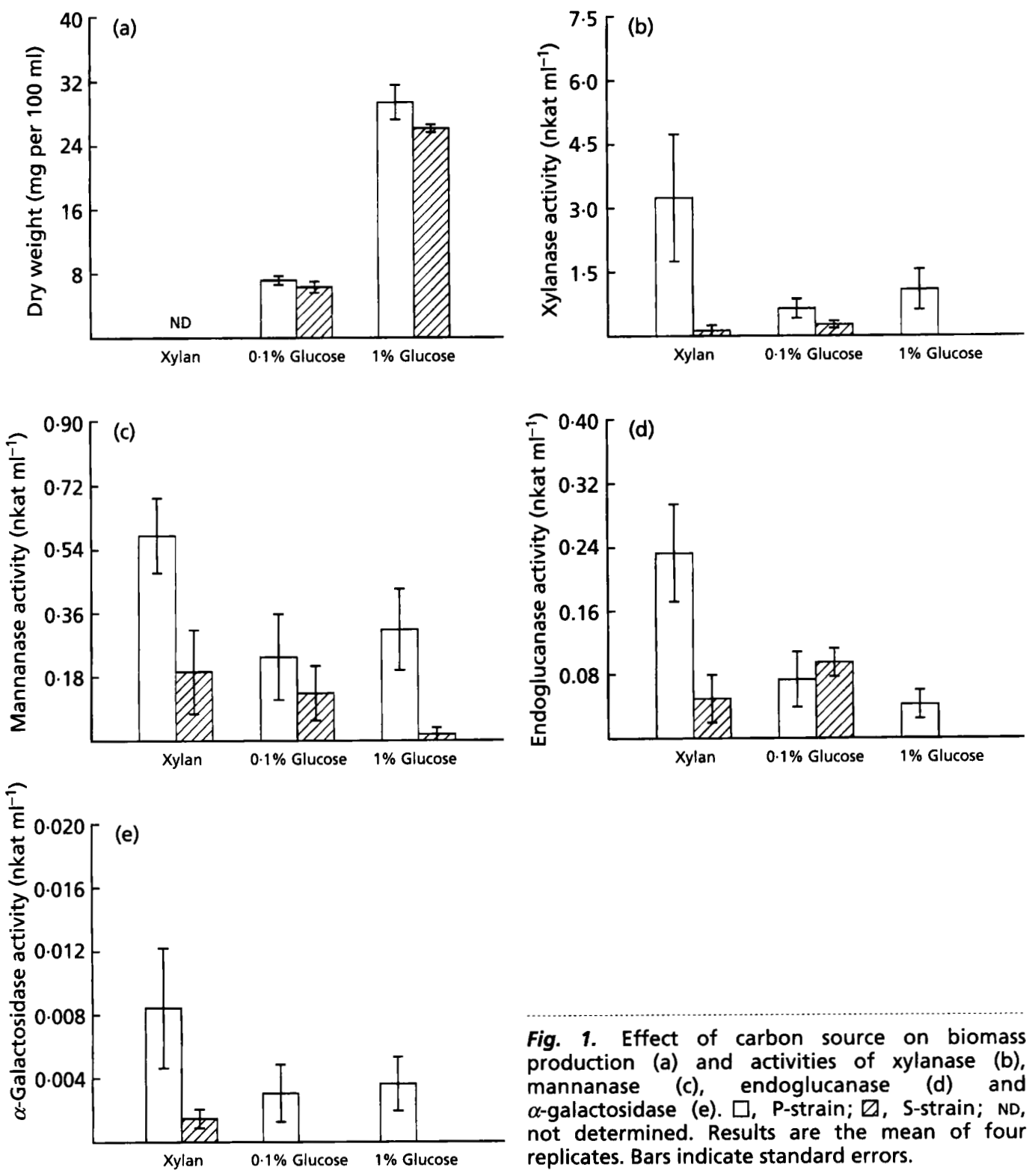

Fig. 1. Effect of carbon source on biomass production (a) and activities of xylanase (b), mannanase (c), endoglucanase (d) and $\alpha$-galactosidase (e). $\square$, P-strain; $\square$, S-strain; ND, not determined. Results are the mean of four replicates. Bars indicate standard errors. 

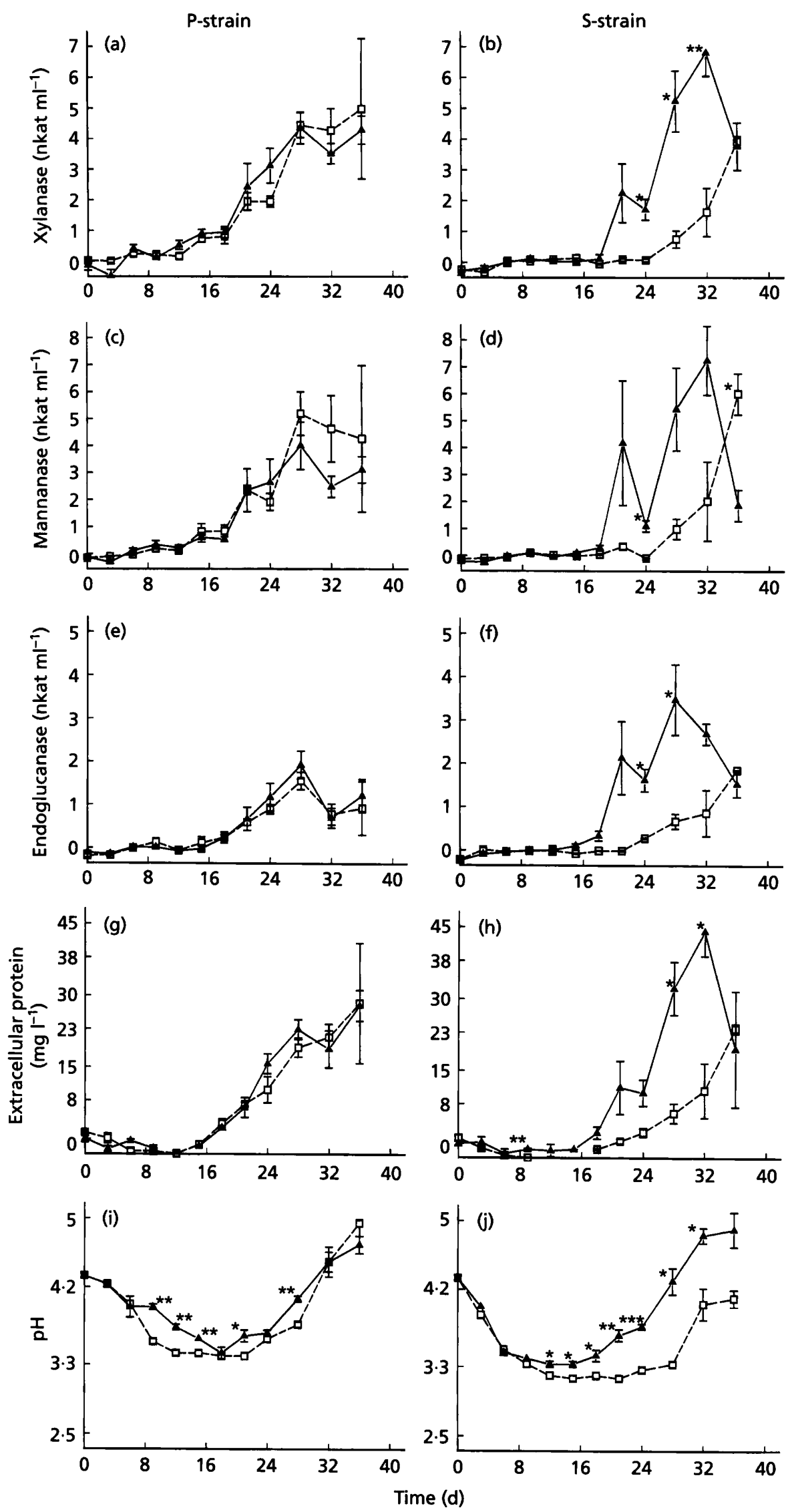

Fig. 2. For legend see facing page. 
Table 1. Hydrolysis products of birch glucuronoxylan after incubation with S-strain birch sawdust culture filtrate

\begin{tabular}{|cccccc|}
\hline $\begin{array}{c}\text { Incubation } \\
\text { time (h) }\end{array}$ & \multicolumn{5}{c|}{ Hydrolysis products $\left(\mathrm{mg} \mathrm{m}^{-\mathbf{1}}\right)$} \\
\cline { 2 - 5 } & Xylose & Xylobiose & Xylotriose & Xylotetraose & Xylopentaose \\
\hline 1 & $\leqslant 0.01$ & 0.22 & 0.14 & 0.04 & ( \\
4 & 0.02 & 0.29 & 0.15 & 0.04 & 0.02 \\
20 & 0.06 & 0.35 & 0.08 & 0.03 & 0.01 \\
\hline
\end{tabular}

mannanase, endoglucanase and $\alpha$-galactosidase activities were produced by the P-strain in all culture media and by the S-strain in most cultures. The highest enzyme activities were produced when the P-strain was grown with xylan as the sole carbon source. The xylanase activity was notably higher than the mannanase and the endoglucanase activities when the activity units used were compared (Fig. 1b-e). Occasionally, low amounts of $\beta$ glucosidase, $\beta$-xylosidase and esterase activities were detected in cultures on pure xylan. In the pure xylan medium, reducing sugars accumulated to approximately $2 \mathrm{mg} \mathrm{ml}^{-1}$. Low xylanase, mannanase and endoglucanase activities were detected also in $0.1 \%$ glucose medium in both $\mathrm{P}$ - and S-strains and in $1 \%$ glucose medium in the Pstrain.

The influence of a supporting carrier matrix on hydrolytic enzyme secretion of the S-strain was tested using the following carbon sources: malt extract with beechwood xylan (malt xylan medium), beechwood xylan, pine sawdust and birch sawdust. Half of the flasks were filled with the carrier matrix. The highest hemicellulolytic and cellulolytic activities were produced in cultures where the mycelium had grown with birch sawdust as a carbon source. In the carrier bound cultures the xylanase, mannanase and endoglucanase activities were higher than in free cell cultures, except in malt xylan medium. In this culture medium no stimulatory effect due to the presence of the carrier matrix was observed. Small amounts of $\beta$ glucosidase, $\beta$-xylosidase, $\alpha$-galactosidase, NA-esterase and acetylxylan esterase activities were detected in all culture media (data not shown).

The production of extracellular enzymes by P- and Sstrains was studied in more detail on birch sawdust as the sole carbon source, since the highest enzyme activities were obtained on this substrate in the S-strain. The free cell and carrier bound cultures were inoculated with conidia from P- or S-strains. In all experiments in which the S-strain mycelium was grown with the carrier matrix, the amounts of xylanase, mannanase and endoglucanase activities and total extracellular proteins (Fig. $2 \mathrm{~b}, \mathrm{~d}, \mathrm{f}, \mathrm{h}$ ) were higher than in the corresponding free cell cultures. In the P-strain cultures the carrier matrix had no effect on

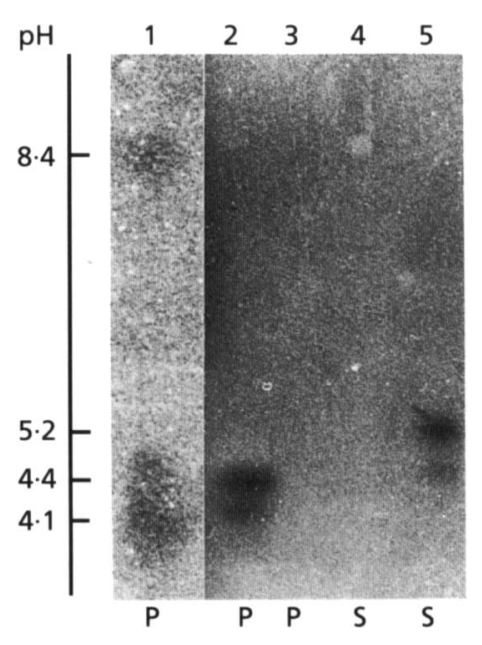

Fig. 3. Xylanase activity visualized by isoelectric focusing using xylan-containing agar replicas. Lane 1, P-strain grown on pure xylan; lanes 2-5, P- and S-strains grown on birch sawdust. P, Pstrain; S, S-strain; lanes 2 and 5, 28-36 d cultures; lanes 3 and 4, $0-6 \mathrm{~d}$ cultures.

the enzyme activity levels or protein secretion (Fig. 2a, c, $e, g)$.

In both strains the $\mathrm{pH}$ in the cultures fell within $12 \mathrm{~d}$ to below 3.5. In the P-strain only minor differences existed in $\mathrm{pH}$ values between carrier bound and free cell cultures. In both culture types after $18 \mathrm{~d}$ growth the $\mathrm{pH}$ of the culture was 3.4 and it increased gradually to 4.7 at the end of the cultivation period (Fig. 2i). In the S-strain carrier bound cultures the $\mathrm{pH}$ fell less and started to increase earlier and rose more than in the free cell cultures (Fig. 2j).

The ability of concentrated enzyme solutions to hydrolyse birch glucuronoxylan was assayed by HPLC. The increase in different xylooligosaccharides in samples incubated for 1,4 and $20 \mathrm{~h}$ further proved the presence of xylanolytic activity in the culture filtrates (Table 1). Xylobiose was the main hydrolysis product. In addition, xylose and xylotriose were formed.

Fig. 2. Comparison of xylanase $(a, b)$, mannanase $(c, d)$ and endoglucanase $(e, f)$ activities, total extracellular protein production $(g, h)$ and $\mathrm{pH}(\mathrm{i}, \mathrm{j})$ in free cell and carrier bound cultures in P-strain (left) and S-strain (right) cultures of $H$. annosum. Each value is a mean of three (days 0-32) or two (day 36) replicates. Broken line, free cell culture; solid line, carrier bound culture. Asterisks represent levels of significance: $*, P<0.05 ; * *, P<0.01 ; * * *, P<0.001$. Bars indicate standard errors. 
(a)

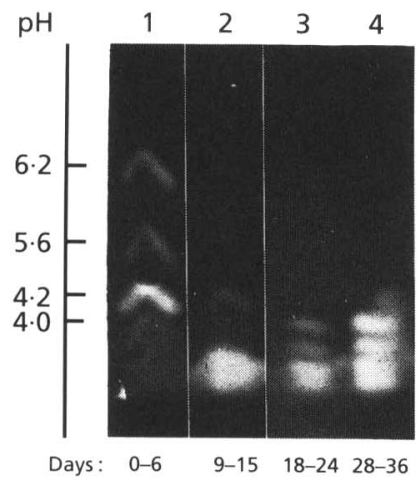

(b)

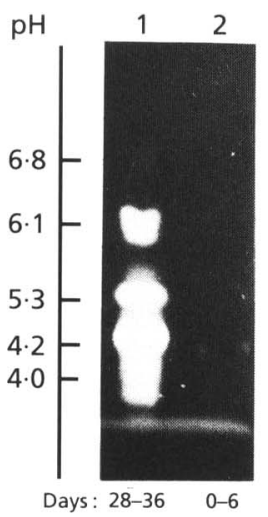

(c)

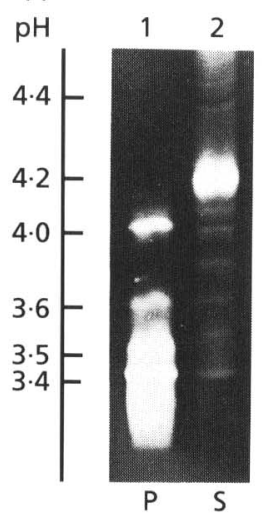

Fig. 4. Mannanase activity visualized by isoelectric focusing using mannan-containing agar replicas. (a) P-strain mannanase activity during growth on birch sawdust at different stages of cultivation, (b) S-strain mannanase at 28-36 d (lane 1) and at $0-6 \mathrm{~d}$ (lane 2) cultivation, (c) P- and S-strain mannanases at 28-36 d cultivation (lanes 1 and 2, respectively).

\section{Isoelectric focusing}

The xylanase, mannanase and cellulase isoenzymes produced by $H$. annosum $\mathrm{P}$ - and S-strains were examined by isoelectric focusing. When xylanolytic activity in culture filtrates was visualized, both in P- and S-strains at least two closely located bands with pI values of $4 \cdot 0-4 \cdot 5$ were seen. A band with pI 8.4 was distinguished in the P- but not in the S-strain (Fig. 3, lane 1). In cultures with birch sawdust as carbon source, no xylanolycic activity was observed by isoelectric focusing during the first $6 \mathrm{~d}$ of cultivation (Fig. 3, lanes 3 and 4 ). In a sample pooled from 28,32 and $36 \mathrm{~d}$ culture filtrates two xylanase bands occurred in both P- and S-strains. The isoenzymes of the $\mathrm{P}$ - and S-strains were slightly different. The P-strain xylanases had more acid $\mathrm{pI}$ values than those of the Sstrain. In these cultivations the xylanase band with a basic pI was absent (Fig. 3, lane 2). Some xylanase activity was present also in $0.1 \%$ glucose medium in the P-strain cultures (not shown).

In the $\mathrm{P}$ - and S-strains multiple forms of mannanases were produced (Fig. 4a, b, c). Isoelectric focusing of the Pstrain culture filtrates taken from very early stages of
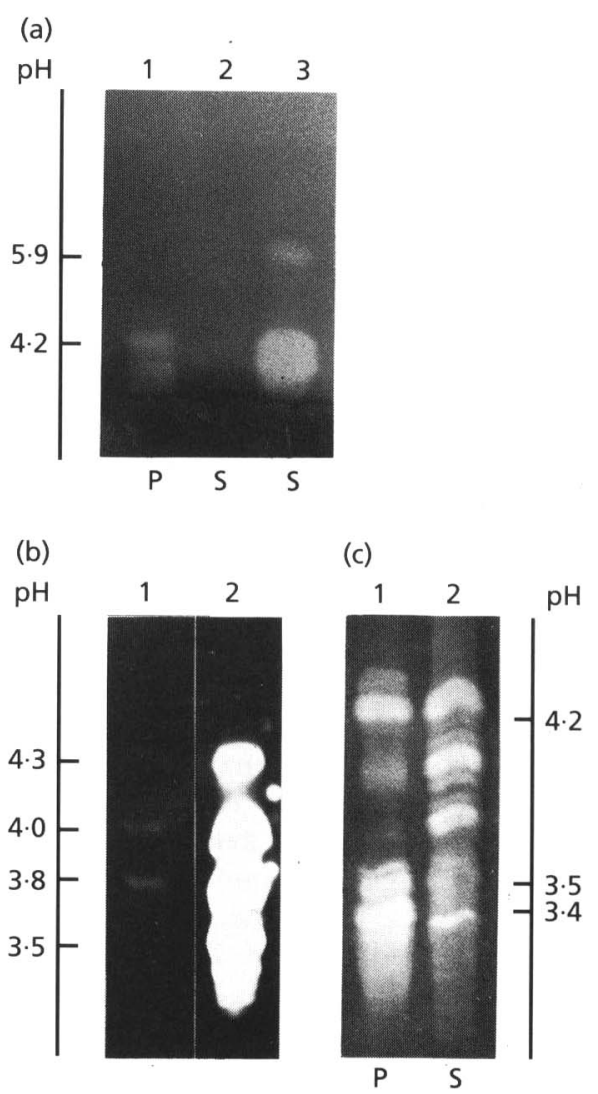

Fig. 5. Endoglucanase activity visualized by isoelectric focusing using hydroxyethylcellulose-containing agar replicas. (a) Samples from P- and S-strain at 28-36 d cultivation (lanes 1 and 3 , respectively) and S-strain at 0-6 d cultivation (lane 2) on birch sawdust, (b) S-strain culture filtrates from glucose (lane 1) and from birch sawdust (lane 2) medium, (c) P- and S-strain endoglucanases at 28-36 d cultivation (lanes 1 and 2 , respectively).

growth (0-6 d) showed mannanase activity in the acid range (3.8-6.2). These mannanase bands were not detected after a longer growth period (18-36 d). Instead, more acid bands ( $\mathrm{pI}$ below $4 \cdot 0$ ) replaced the $\mathrm{pI} 3 \cdot 8-6 \cdot 2$ bands (Fig. $4 a)$. In contrast to the P-strain no or very little mannanase activity was detected by isoelectric focusing in the early stage of the cultures in the S-strain (Fig. 4b, lane 2). However, in this strain the mannanase activity increased with the culture age, and the $\mathrm{pI}$ values of the mannanases from the later stages of the growth were comparable to those of the early stages of the growth in the P-strain ( $\mathrm{pI}$ values approx. 6.2, 5.3 and 4.2; Fig. 4b, lane 1 ).

Most of the endoglucanase isoforms of the P- and Sstrains were separated properly only when an acid $\mathrm{pH}$ range $2 \cdot 5-5 \cdot 0$ was used (Fig. 5a, b, c). However, in the Sstrain one band with pI 5.9 appeared (Fig. 5a, lane 3). No activity was observed in the early stages of growth (Fig. $5 a$, lane 2). The relative intensities of the individual bands varied in $\mathrm{P}$ - and S-strains in the later stages of growth. In the P-strain strong bands occurred at pI values of $4 \cdot 2,3 \cdot 5$ and $3 \cdot 4$, whereas in the $S$-strain the bands with $\mathrm{pI}$ values 
of $4 \cdot 2,4 \cdot 0,3 \cdot 8$ and $3 \cdot 4$ were the strongest (Fig. $5 c$, lanes 1 and 2). When S-strain cultures from the glucose medium were analysed for endoglucanase activity, four weak bands were detected with pI values of approximately $4 \cdot 3$, $4 \cdot 0,3 \cdot 8$ and $3 \cdot 5$. These bands were much stronger when cultures with birch sawdust as the only carbon source were analysed (Fig. 5b). No qualitative differences in the enzyme activities were found between the free cell and the carrier bound cultures.

\section{DISCUSSION}

In $H$. annosum the hemicellulolytic enzymes xylanase, mannanase and $\alpha$-galactosidase were detected in the presence of $0.1 \%$ glucose in the $\mathrm{P}$ - and S-strains and in the presence of $1 \%$ glucose in the P-strain; hence some hemicellulolytic activity appears to be constitutive. In Phanerochaete chrysosporium constitutive xylanase production has been recently reported (Copa-Patiño et al., 1993). In contrast to hemicellulolytic enzymes, no or very low endoglucanase activity was detected with $1 \%$ glucose in the culture medium, although the fungal biomass production was increased. This is in accordance with the known properties of cellulase biosynthesis and secretion which are repressed by glucose (Merivuori et al., 1984). In the presence of complex carbon sources, such as birch sawdust, the activity of all the enzymes was clearly increased. These results obtained with $H$. annosum agree well with other reports on enzymic activities in white-rot basidiomycetes such as Ischoderma resinosum (Sutherland, 1986) and Pblebia (Merulius) tremellosa (Reid \& Deschamps, 1991 ) in which the selective degradation of lignin in wood is facilitated by hemicellulolytic enzymes.

In media containing complex carbon sources and a carrier matrix, the hydrolytic activities increased significantly in the S-strain. Similar polypropylene matrices have been used successfully in lignin peroxidase and laccase production experiments with Phlebia radiata (Kantelinen et al., 1989). In the P-strain no increase in hydrolytic enzyme activity in the carrier bound cultures could be observed; neither was marked increase in the enzyme activity observed in S-strain cultures provided with carrier matrices in the malt xylan medium. The reasons why a carrier matrix increases hydrolytic enzyme activity in certain fungi and strains are not totally understood. Cellulolytic (avicelase) and xylanase activities in some basidiomycetes including two strains of $H$. annosum have been reported to differ depending on whether they were grown in liquid or on solid media (Hegarty et al., 1987). In the present work it was not possible to measure the biomass production in the carrier bound cultures containing insoluble substrates, and therefore the possibility that the increased enzyme activities in the culture medium were merely due to increased growth of the S-strain could not be ruled out. The levels of enzyme activities and extracellular proteins were very similar in the free cell cultures of the S-strain, and in the free cell and carrier bound cultures of the P-strain. This excludes the possibility that the lower viability and germination rate of the P-strain conidia caused the low activity in the carrier bound cultures of the P-strain. Further studies to clarify the effect of the supporting matrix upon the secretion machinery are required.

In this study elevated $\mathrm{pH}$ values correlated positively with enzyme activities in both $\mathrm{P}$ - and S-strains of $H$. annosum. A similar increase in $\mathrm{pH}$ of the culture medium after a certain period of growth on different carbon sources has been reported in H. annosum (Johansson, 1988), Schizophyllum commune (Haltrich et al., 1993) and P. chrysosporium (Bonnarme et al., 1993; Leštan et al., 1994). Several metabolic events in a mycelium may lead to the change in culture medium $\mathrm{pH}$. To determine whether the increase in the culture medium $\mathrm{pH}$ in $\mathrm{P}$ - and S-strains of $H$. annosum was merely due to increased growth or to the onset of secondary metabolism requires further experiments.

The $\mathrm{P}$ - and S-strains of H. annosum each had a characteristic xylanase isoenzyme pattern. The P-strain pattern resembled that of several Trichoderma species (Poutanen $e t$ al., 1987; Biely \& Markovic, 1988). The xylanase band of the P-strain with pI 8.4 was present when the carbon source was pure xylan, but absent when birch sawdust was used as a carbon source. Also, in T. reesei the occurrence of the alkaline xylanase ( $\mathrm{pI} 8.5$ ) activity is dependent on the carbon source (Herzog et al., 1992).

In Trichoderma, only two of the xylanolytic enzymes have been reported to be specific xylanases, the others being classified as unspecific endoglucanases (Kolarova \& Farkas, 1983; Biely \& Markovic, 1988; Claeyssens et al., 1990; Tenkanen et al., 1992). This could also be the case in $H$. annosum, since hydroxyethylcellulose-degrading activity was observed in the acid part of the isoelectric focusing gel where the xylanase bands occurred. In the basic region of the gel no hydroxyethylcellulosedegrading activity was observed, which may indicate that the xylanase with $\mathrm{pI} 8.4$ in the P-strain exhibited true xylanolytic activity.

In the P-and S-strains multiple forms of mannanases were produced. The mannanases of Polyporus (Trametes) versicolor (Johnson \& Ross, 1990), Thielavia terrestris (Araujo \& Ward, 1990), Trichoderma reesei (Ståhlbrand et al., 1993) and T. barzianum (Torrie et al., 1990) are also reported to occur as several isoenzymes. In earlier studies of $H$. annosum (Fomes annosus) (Ahlgren \& Eriksson, 1967) all mannanase activities had $\mathrm{pI}$ values below $\mathrm{pH} 4 \cdot 2$, resembling the P-strain enzyme pattern in this study. The activities of the mannanases and the xylanases overlapped those of the endoglucanases in the isoelectric focusing gel. Whether the mannanases and the xylanases show unspecific activity remains unanswered until the mannanases are purified and characterized. However, the recently purified $T$. reesei mannanases were not active against hydroxyethylcellulose or xylan (Arisan-Atac et al., 1993; Ståhlbrand et al., 1993).

\section{ACKNOWLEDGEMENTS}

This work was supported by the Nordic Joint Committee for Agricultural Research. The help of $\mathrm{Mr} \mathrm{H}$. Liehu in statistical analysis, and Dr K. Fagerstedt for revising the language, is acknowledged. 


\section{REFERENCES}

Ahlgren, E. \& Eriksson, K.-E. (1967). Characterization of cellulases and related enzymes by isoelectric focusing, gel filtration and zone electrophoresis. II. Studies on Stereum sanguinolentum, Fomes annosus and Chrysosporium lignorum enzymes. Acta Chem Scand 21, 11931200 .

Araujo, A. \& Ward, O. P. (1990). Purification and some properties of the mannanases from Thielavia terrestris. J Ind Microbiol 6, 269-274.

Arisan-Atac, I., Hodits, R., Kristufek, D. \& Kubicek, C. P. (1993). Purification and characterization of a $\beta$-mannanase of Trichoderma reesei C-30. Appl Microbiol Biotechnol 39, 58-62.

Bailey, M. J., Biely, P. \& Poutanen, K. (1992). Interlaboratory testing of methods for assay of xylanase activity. $J$ Biotechnol 23, 257-270.

Béguin, P. (1983). Detection of cellulase activity in polyacrylamide gels using congo red-stained agar replicas. Anal Biochem 131, 333-336.

Biely, P. \& Markovic, O. (1988). Resolution of glycanases of Trichoderma reesei with respect to cellulose and xylan degradation. Biotechnol Appl Biochem 10, 99-106.

Bonnarme, P., Delattre, M., Drouet, H., Corrieu, G. \& Asther, M. (1993). Toward a control of lignin and manganese peroxidases hypersecretion by Phenerochaete chrysosporium in agitated vessels: evidence of the superiority of pneumatic bioreactors on mechanically agitated bioreactors. Biotechnol Bioeng 41, 440-450.

Brown, M. T. \& Wilkins, D. A. (1985). Zinc tolerance of mycorrhizal Betula. New Pbytol 99, 101-106.

Claeyssens, M., van Tilbeurgh, H., Kamerling, J. P., Vrsanska, M. \& Biely, P. (1990). Studies of the cellulolytic system of the filamentous fungus Trichoderma reesei QM9414. Substrate specificity and transfer activity of endoglucanase I. Biochem J 270, 251-256.

Copa-Patiño, J. L., Young, G. K. \& Broda, P. (1993). Production and initial characterization of the xylan-degrading system of Phanerochaete chrysosporium. Appl Microbiol Biotechnol 40, 69-76.

Haltrich, D., Preiss, M. \& Steiner, W. (1993). Optimization of a culture medium for increased xylanase production by a wild strain of Schizophyllum commune. Enzyme Microb Technol 15, 854-860.

Hegarty, B., Steinfurth, A., Liese, W. \& Schmidt, O. (1987). Comparative investigations on wood decay and cellulolytic and xylanolytic activity of some basidiomycete fungi. Holvforschung 41, 265-269.

Herzog, P., Törrönen, A., Harkki, A. \& Kubicek, C. P. (1992). Mechanism by which xylan and cellulose trigger the biosynthesis of endoxylanase I by Trichoderma reesei. In Xylans and Xylanases, pp. 289-293. Edited by J. Visser, G. Beldman, M. A. Kusters-van Someren \& A. G. J. Voragen. Amsterdam: Elsevier.

Hodges, C. S. (1969). Modes of infection and spread of Fomes annosus. Annu Rev Phytopatbol 7, 247-266.

Hutterman, A. \& Volger, C. (1973). Induction of aryl- $\beta$-glucosidase in Fomes annosus by cellobiose. Arch Mikrobiol 93, 195-204.

Johansson, M. (1988). Pectic enzyme activity of spruce (S) and pine (P) strains of Heterobasidion annosum (Fr.) Bref. Physiol Mol Plant Patbol 33, 333-349.

Johansson, M., Popoff, T. \& Theander, O. (1976). Effect of spruce constituents on extracellular enzymes of Fomes annosus. Physiol Plant 37, 275-282.

Johnson, K. G. \& Ross, N. W. (1990). Enzymic properties of $\beta$ mannanase from Polyporus versicolor. Enzyme Microb Tecbnol 12, 960-964.

Kantelinen, A., Hatakka, A. \& Viikari, L. (1989). Production of lignin peroxidase and laccase by Pblebia radiata. Appl Microbiol Biotechnol 31, 234-239.

Kolarova, N. \& Farkas, V. (1983). Laminarinases, xylanases and amylases in the crude cellulolytic enzyme complex from Trichoderma reesei. Biologia (Bratisl) 38, 721-725.

Korhonen, K. (1978). Intersterility groups of Heterobasidion annosum. Commun Inst For Fenn 94, 1-25.

Leštan, D., Leštan, M. \& Perdih, A. (1994). Physiological aspects of biosynthesis of lignin peroxidases by Phanerochaete chrysosporium. Appl Environ Microbiol 60, 606-612.

Maijala, P., Fagerstedt, K. V. \& Raudaskoski, M. (1991). Detection of extracellular cellulolytic and proteolytic activity in ectomycorrhizal fungi and Heterobasidion annosum (Fr.) Bref. New Phytol 117, 643-648.

Merivuori, H., Siegler, K. M., Sands, J. A. \& Montenecourt, B. S. (1984). Regulation of cellulase biosynthesis and secretion in fungi. Biochem Soc Trans 13, 411-414.

Poutanen, K. \& Puls, J. (1988). Characteristics of Trichoderma reesei $\beta$-xylosidase and its use in the hydrolysis of solubilized xylans. Appl Microbiol Biotechnol 28, 425-432.

Poutanen, K. \& Sundberg, M. (1988). An acetyl esterase of Trichoderma reesei and its role in the hydrolysis of acetyl xylans. Appl Microbiol Biotechnol 29, 300-306.

Poutanen, K., Răttơ, M., Puls, J. \& Viikari, L. (1987). Evaluation of different microbial xylanolytic systems. J Biotechnol 6, 49-60.

Reid, I. D. \& Deschamps, A. M. (1991). Nutritional regulation of synthetic lignin (DHP) degradation by the selective white-rot fungus Phlebia (Merulius) tremellosa: effects of glucose and other cosubstrates. Can J Bot 69, 147-155.

Rătto, M. \& Poutanen, K. (1988). Production of mannan-degrading enzymes. Biotechnol Lett 10, 661-664.

Ståhlbrand, H., Siika-Aho, M., Tenkanen, M. \& Viikari, L. (1993). Purification and characterization of two $\beta$-mannanases from Trichoderma reesei. J Biotechnol 29, 229-242.

Stenlid, J. \& Swedjemark, G. (1988). Differential growth of S- and P-isolates of Heterobasidion annosum in Picea abies and Pinus sylvestris. Trans Br Mycol Soc 90, 209-213.

Sumner, J. B. \& Somers, G. F. (1949). Dinitrosalisylic method for glucose. In Laboratory Experiments in Biological Chemistry, pp. 38-39. Edited by J. B. Sumner. New York: Academic Press.

Sutherland, J. B. (1986). Regulation of cellulolytic activity in the white-rot fungus Ischnoderma resinosum. Mycologia 78, 52-55.

Tenkanen, M., Puls, J. \& Poutanen, K. (1992). Two major xylanases of Trichoderma reesei. Enzyme Microb Technol 14, 566-574.

Torrie, J. P., Senior, D. J. \& Saddler, J. N. (1990). Production of $\beta$ mannanases by Trichoderma barzianum E58. Appl Microbiol Biotechnol 34, 303-307.

Received 16 June 1994; revised 9 September 1994; accepted 1 November 1994. 